\title{
Is Aid for Trade Effective? A Panel Quantile Regression Approach
}

\author{
by \\ Inmaculada Martínez-Zarzoso* ${ }^{1}$, University of Goettingen and University Jaume I \\ Felicitas Nowak-Lehmann D.*, University of Goettingen \\ Kai Rehwald**, University of Aarhus \\ Preprint version. Published in the Review of Development Economics, 2017
}

\begin{abstract}
This paper investigates whether Aid for Trade (AfT) leads to greater exports in recipient countries. Using panel data and panel quantile regression techniques, our results suggest that total AfT disbursements promote the export of goods and services, but is limited primarily to exporters above the .35 quantile of the conditional distribution of exports. When disaggregating by type of AfT, we find that aid to improve trade policy and regulation is not associated with higher exports. Aid to build productive capacity is effective for almost all quantiles of the export distribution but the 10th, with the effect being stronger at the higher tails of the conditional distribution. Aid used to build infrastructure is found to affect exports only at the 0.10 quantile. In contrast, aid disbursed for general budget support (an untargeted type of aid) is not associated with greater export levels irrespective of the quantile.
\end{abstract}

Key Words: development aid; North-South trade; aid for trade; panel data; aid effectiveness

JEL Codes: F14, F35, O10, C22, C23

* Department of Economics, University of Goettingen, Platz der Goettinger Sieben 3, 37073, Goettingen, Germany. Tel: 0049551397487; Fax: 0049551398173; e-mail: fnowak@uni-goettingen.de (corresponding author: Felicitas Nowak-Lehmann D.).

**Department of Economics, University of Aarhus, Nordre Ringgade 1DK-8000 Aarhus.

\footnotetext{
1 The authors would like to thank the participants of the research seminar held at the University of Bochum, the International Economics Workshop held in Goettingen and the DEGIT Conference in Geneva for their helpful comments and suggestions, which have been incorporated into the paper. Inmaculada Martinez-Zarzoso would like to acknowledge the funding received from the Spanish Ministry of Economy and Competitiveness (project ECO2014-58991-C3-2-R) and Universitat Jaume I (P1- 1B2013-06).
} 


\section{Is Aid for Trade Effective? A Panel Quantile Regression Approach}

\section{Introduction}

Aid for Trade (AfT) became a buzz word in aid policy just a few years ago, but is far from being a new concept in development policy (Evenett, 2009). Dating back to the 1986-1994 Uruguay Round of the Multilateral Trade Negotiations (MTN), developing countries began demanding financial compensation for concessions made in trade liberalization negotiations ${ }^{2}$ as well as an increase in development aid to help facilitate integration into the world trading system. Aid that serves the latter objective is usually considered AfT. As trade liberalization negotiations became more problematic in the late 1990s and early 2000s given that the "easier" concessions had already been made on both sides (developed and developing countries), WTO members separated the AfT initiative from the Doha Round negotiations and established a WTO 'Aid for Trade Task Force' in July 2006. According to the WTO AfT task force, the objectives of the AfT initiative are to promote growth and development through trade across developing countries, especially in the least developed countries (LDCs); and through their integration into the world trading system. This is achieved through a more trade-oriented infrastructure, an improved production capacity, and by supporting negotiations concerning trade policy regulation and trade liberalization. As AfT is considered an important instrument for development aid, the European Union, the United States, and Japan made non-binding concessions to increase AfT disbursements. However, the means for AfT have not increased substantially (García, 2008; Luke, 2009; Huchet-Bourdon et al., 2009; Karingi, 2009). In the period from 2002 to 2009 , AfT ranged from only 20 to $30 \%$ of total official development assistance (ODA). Although AfT did increase during this period, other types of aid increased

\footnotetext{
${ }^{2}$ Compensation payments for trade liberalization were the original type of AfT.
} 
even faster (Karingi, 2009). In Africa, the AfT share shrank from 29\% in 2002 to $21 \%$ in 2006. In real terms, 2010 AfT commitments were extremely high at US\$ 48 billion, falling by $14 \%$ to US\$ 41 billion in 2011. Meanwhile, AfT disbursements were less affected by the 2011 decline in ODA; disbursements declined by only $3.7 \%$ to US\$ 33.5 billion.

In recent years, development economists have become more aware of the challenges of overall ODA in promoting trade and economic growth in developing countries (Doucouliagos and Paldam, 2008; Rajan and Subramanian, 2008; Nowak-Lehmann D. et al., 2012; NowakLehmann D. et al., 2013). Many existing studies find that ODA is ineffective, in that it produces no significant impact on per capita income and recipient-country exports. However, these studies fail to differentiate ${ }^{3}$ between the different types of aid, such as: AfT, technical assistance, humanitarian aid, sector-specific aid, etc. This could explain why the authors of this paper were unable to find a positive impact of aid.

Given the objectives of AfT, the question remains: Is AfT effective? In particular, we investigate whether AfT is associated with higher exports of goods and services. To the best of our knowledge, existing literature on AfT-effectiveness is scarce, as pointed out by Vijil and Wagner (2012), and most of the work consists of case studies at the country level. The main contribution of this paper to existing literature is its methodological approach using panelquantile regression techniques, which allows us to investigate whether AfT has different effects along the conditional distribution of exports while controlling for unobserved country heterogeneity. More specifically, we study whether AfT benefits countries that have certain export disadvantages and therefore have a weaker export capacity. Being able to answer this question is extremely relevant as it would facilitate the better targeting of AfT funds based on the export capacity and AfT efficiency of the recipient countries.

The main results show that total AfT disbursements and its sub-categories do not always promote exports of goods and services with respect to average size exporters over the period

\footnotetext{
${ }^{3}$ Rajan and Subramanian (2009) investigated different types of aid but could not establish significant differences between these types.
} 
from 2002 to 2011. We find that exporters only benefit at certain quantiles of the conditional distribution of exports and from certain AfT categories. In particular, aid used to improve trade policy and trade regulation does not affect exports, whereas aid to build production capacity does with relatively high impacts for the $0.35,0.50,0.75$ and 0.90 quantiles of the export distribution. Aid used to build economic infrastructure also positively affects exports, but only for the 0.1 quantile of the distribution. This is good news as it shows that aid is effective for the more disadvantaged countries that have a greater need for economic infrastructure. Conversely, aid disbursed to general budget support (a control variable), which is considered to be an untargeted component of development aid, is not associated with higher exports. It even has a negative contribution on export expansion. This holds true irrespective of the quantile.

The rest of the paper is structured as follows. Section 2 presents the empirical model that we use to analyse AfT effectiveness. Section 3 discusses the variables, data and descriptive statistics. Regression results are presented and evaluated in Section 4, and Section 5 contains the concluding remarks.

\section{Literature review}

The effectiveness of AfT is currently assessed using one of two approaches. The first approach examines whether AfT reduces the cost of trading or other impediments to trade. Calì and te Velde (2011) and Busse et al. (2011) find that aid for infrastructure and aid for trade facilitation lower transport costs and thus promote exports. The second approach, which is used in this paper, analyses whether AfT is directly associated with improved export performance (measured by the value of exports of goods and services). Earlier studies found a positive relationship between AfT or at least some of its components, and trade-related outcomes. Among these studies, Bearce et al. (2013) find that AfT issued by the US government has a positive effect on the recipient country's export performance; Vijil and Wagner (2012) suggest that aid to trade- 
related infrastructure ${ }^{4}$, as part of overall AfT, has a positive impact on exports as a ratio to GDP; and Calì and te Velde (2011) find that AfT has an overall positive and significant effect on exports, driven by AfT for economic infrastructure which has the additional effect of lowering trade costs. Both Vijil and Wagner (2012) and Calì and te Velde (2011) emphasize that the infrastructure channel is the main driver of AfT effectiveness. However, Helble, Mann and Wilson (2012) find that aid for trade policy and regulations (another AfT category) is also effective. The authors find that a $1 \%$ increase in aid for trade policy and regulation increases trade value by around US\$ 347 million. Hühne et al. (2014) investigated the impact of AfT on both donor and recipient countries. For recipient countries, they find total AfT and its components (infrastructure-related aid, aid for building and improving productive capacity and aid for trade policy and regulation) are all effective. However, when breaking the sample down into groups by income and region, the results become mixed. AfT tends to favour the richer developing countries and countries in Asia and Latin America. None of the revised studies examine the effect of AfT along the distribution of exports, which is the central focus of this paper.

\section{Empirical Model}

\subsection{Baseline model}

As a framework for analysis, we estimate the model proposed by Calì and te Velde (2011) using the latest AfT data. The authors identify the types of AfT that can help address governance failures in developing countries by associating the main aid categories, as classified by OECD statistics, with a number of goals that are related to trade performance, e.g. aid for trade policy and regulations should improve weak institutions. They also refer to the complexity of the economic channels through which AfT affects export performance. This includes Dutch-disease effects as well as direct and indirect competitiveness effects. The authors claim, however, that causality is less complex than for the aid-economic growth link.

\footnotetext{
${ }^{4}$ Throughout this paper, we refer to this type of aid as "aid for economic infrastructure".
} 
The empirical model used to analyse AfT effectiveness is an export demand equation augmented with aid for trade variables and is given by:

$$
\operatorname{Exp}_{i t}=\beta_{0}+\sum_{k} \beta_{k} X_{k i t}+\sum_{l} \beta_{l} D_{l t}+\alpha_{i}+\varepsilon_{i t}
$$

where $\operatorname{Exp}_{i t}$ denotes exports of country $i$ in year $t, X_{k i t}$ are explanatory variables (AfT and a number of control variables), $D_{l t}$ are time dummies, $\alpha_{i}$ denotes country-specific unobserved heterogeneity, and $\varepsilon_{i t}$ is the error term. The unobserved effects, $\alpha_{i}$, are country-specific and time-invariant and represents unobserved country heterogeneity that can be treated as fixed or random to fit the model. The baseline is the following static unobserved effects model:

$\ln \left(\operatorname{Exp}_{i t}\right)=\beta_{0}+\beta_{1} P O P_{i t}+\beta_{2} \ln \left(M P_{i t}\right)+\beta_{3} G E_{i t}+\beta_{4} \ln \left(C P I_{i t}\right)+\sum_{h} \beta_{h} \ln \left(A f T_{h i t-x}\right)+$

$\sum_{l} \beta_{l} D_{l t}+\alpha_{i}+\varepsilon_{i t}$

where $\ln$ denotes natural logs. We regress exports $\left(\operatorname{Exp}_{i t}\right)$ on lagged proxies for AfT $\left(A f T_{h i t-x}\right)$ while controlling for population size $\left(P O P_{i t}\right)$, market potential $\left(M P_{i t}\right)$, government effectiveness $\left(G E_{i t}\right)$ and the consumer price index $\left(C P I_{i t}\right)$. Time dummies $\left(D_{l t}\right)$ and the country-unobserved effects $\left(\alpha_{i}\right)$ are also included.

Model (2) is a generalized version of the model used by Calì and te Velde (2011: 730). There are two main differences. First, we use exports of goods and services as a dependent variable, whereas the authors use merchandise exports. Second, the authors use only two AfT categories, while we use three.

The reasons for our choice of dependent and explanatory variables are as follow. First, there is no reason to limit the scope of analysis to merchandise exports. Service exports, for example, could also be fostered by AfT. AfT is not aimed exclusively at merchandise exports 
nor would we expect the export performance of service sectors to be unaffected by AfT. ${ }^{5}$ Consequently, we use exports of goods and services as the dependent variable in our regressions. Second, when analysing the effect of AfT on exports, a specific measure of AfT must be selected (i.e. selecting which AfT categories to include in the estimations). Calì and te Velde (2011) only use aid disbursed for economic infrastructure (CRS category 200) and aid disbursed to production capacity (CRS category 300). Unlike their study, we make use of three AfT proxies: aid to trade policies and regulation $(T P R)$, aid to economic infrastructure $(E I)$ and aid to building production capacity $(B P C)$. Our choice of AfT proxies allows us to be more specific and its components are listed in Table A.1.

To put our results into perspective, we compare the impact of AfT with the impact of aid to general budget support $(G B S)$, which is non-targeted and might be used by recipients for trade development but it is not included in total AfT. Lastly, we experiment with three alternative measures of market potential. The concept of market potential dates back to Harris (1954). Calì and te Velde (2011: 730) calculate the market potential ${ }^{6}$ of country $i$ at time $t$ as the sum of the (inverse) bilateral distance $\left(d_{i j}\right)$ weighted GDPs of all other countries, i.e.

$$
M P_{i t}=\sum_{j} \frac{G D P_{j t}}{d_{i j}}
$$

Generally speaking, as Overman, Redding and Venables (2001:12) explain, market potentials can also be computed as:

$$
M P_{\gamma i t}=\sum_{j} G D P_{j t} d_{i j}^{\gamma}
$$

where $\gamma$ serves as a "distance weighting parameter". By varying the size of the distance weighting parameter, we obtain different measures of market potential:

\footnotetext{
${ }^{5}$ Aid for economic infrastructure (which is part of overall AfT and is used to build roads and ports, among other things), may have an impact on the tourism sector (which, especially in developing countries, may account for a substantial portion of total exports).

${ }^{6}$ Note that the market potential of country $i$ at time $t$ is calculated as the sum of the (inverse) bilateral distance weighted GDPs of all other countries and not only of all countries for which we analyse the effect of AfT on exports - which are, of course, mostly developing countries.
} 


$$
\begin{gathered}
M P 1=M P_{i t}(\gamma=-1)=\sum_{j} \frac{G D P_{j t}}{d_{i j}} \\
M P 2=M P_{i t}(\gamma=-0.5)=\sum_{j} \frac{G D P_{j t}}{\sqrt{d_{i j}}} \\
M P 3=M P_{i t}(\gamma=-2)=\sum_{j} \frac{G D P_{j t}}{d_{i j}^{2}}
\end{gathered}
$$

Note that we would expect greater market potential to be (ceteris paribus) associated with higher exports.

Before looking at the impact of AfT and its sub-categories on exports in different quantiles of the export distribution, we want to make sure that we do not run spurious regressions. To this end we test the time-series properties of our series (see Appendix Table A.2) and test for cointegration by means of Kao's and Pesaran's et al. (2011) ${ }^{7}$ cointegration test (see Appendix Table A.3). We find all series to be non-stationary (I(1)) and cointegrated, i.e. they have a systematic relationship in the period under study.

Having found cointegration, we estimate an OLS regression with regional dummies, a fixed-effects model and a dynamic panel-data GMM model, which includes lagged exports as right-hand-side variable and controls for endogeneity of lagged exports and (potentially) AfT. The above-mentioned models are conditional mean regression models and yield our baseline results. The dynamic panel data model is given by:

$$
\begin{aligned}
& \Delta \ln \left(\operatorname{Exp}_{i t}\right)=\beta_{0}+\beta_{1} \Delta P O P_{i t}+\beta_{2} \Delta \ln \left(M P_{i t}\right)+\beta_{3} \Delta G E_{i t}+\beta_{4} \Delta \ln \left(C P I_{i t}\right)+\sum_{h=1}^{H} \delta_{h} \Delta \ln \left(A f T_{h i t}\right)+ \\
& \sum_{l=1}^{L} \lambda_{l} \Delta D_{l t}+\gamma \Delta \ln \left(\operatorname{Exp}_{i, t-1}\right)+v_{i t}
\end{aligned}
$$

\footnotetext{
${ }^{7}$ Pesaran's cointegration test, which is based on an unrestricted Error Correction Model (ARDL) supports the finding of cointegration.
} 
where $h$ is the number of different AfT types, $l$ is the number of time fixed effects, and $\Delta$ stand for the first difference of the variables.

\subsection{Quantile regression model}

A novel specification considered in this paper is the application of a quantile regression for panel data, which was recently proposed by Canay (2011). He suggests a simple transformation to account for fixed effects, assuming that these effects are location shifters. The author develops a two-step approach that consists of estimating country fixed effects (FE) using a within-FE model as a first step. As a second step, the consistently estimated FE are used to demean the dependent variable (log of exports) and this transformed variable is taken as a dependent variable in a quantile regression.

The model estimated in the first step is given by equation (2) above. Then, the estimated $\alpha_{i}$ are used to transform $\ln \left(\operatorname{Exp}_{\mathrm{it}}\right)$ into

$$
\widetilde{X}_{i t}=\ln \left(E X P_{i t}\right)-\hat{\alpha}_{i}
$$

The quantile regression is estimated as:

$$
\hat{\beta}(\tau)=\underset{\beta \in \Theta}{\arg \min }(n T)^{-1} \sum_{T=1}^{T} \sum_{i=1}^{n} \rho_{\tau}\left(\widetilde{X}_{i t}-X_{i t}^{\prime} \beta\right)
$$

\section{Data, variables and main results}

\subsection{Variables, Data and Descriptive Statistics}

In this section, we discuss the data and present variable descriptions and sources, as well as descriptive statistics. The panel dataset used in our empirical analysis covers the period from 2000 to 2011 and comprises 162 countries (see Table A.4 in the Appendix). ${ }^{8}$ Figure A.1 shows the regional distribution. It is worth noting that $19 \%$ of the countries are landlocked. Limited

\footnotetext{
${ }^{8}$ While data on AfT is available for 179 countries, there are only 168 countries where data is available for both AfT and exports, our dependent variable. For 6 of these 168 countries, we are unable to calculate market potentials - an important control variable - because data on bilateral distances is missing. We confine the analysis ex ante to those 162 countries for which data on exports, AfT and bilateral distances (market potentials) are available (which does not mean that the data for these 162 countries is complete).
} 
data availability influenced the time and country dimensions of the panel. In particular, data coverage on AfT for the years before 2000 is incomplete.

Table A.5 presents a description of the variables used in the analysis, the corresponding abbreviations, and the sources of the data. Data on AfT — our key explanatory variable - stems from the Creditor Reporting System (CRS) (OECD, 2013a). ${ }^{9}$ According to the OECD (2013b), "[t]he objective of the CRS Aid Activity database is to provide (...) data that enables analysis on where aid goes, what purposes it serves and what policies it aims to implement (...)." Data on commitments and disbursements of official development assistance (ODA) is available by sector, policy objective, type of aid, and purpose code (see Table A.6). Data on disbursement serve our purpose better as they capture the amounts of aid received by the developing countries under examination. Using ODA data by sector, we calculated AfT proxies as can be seen in Table A.1. The OECD identifies five categories of AfT: (1) technical assistance for trade policy and regulations (e.g. helping countries develop trade strategies, negotiating trade agreements and implementing their outcomes); (2) trade-related infrastructure (e.g. building roads, ports and telecommunication networks to connect domestic markets to the global economy); (3) productive capacity building, including trade development (e.g. providing support to the private sector to exploit their comparative advantages and diversify their exports); (4) trade related adjustments (e.g. helping developing countries finance the costs associated with trade liberalization, such as tariff reductions, preference erosion, or declining terms of trade) and (5) other trade-related needs, identified as trade-related development priorities in partner countries' national development strategies (OECD, 2014). For reasons of data availability, analysis is limited to the first three categories of AfT.

Data on the export of goods and services (in constant 2005 US\$) is from the World Bank's World Development Indicators (WDI) database (World Bank, 2013a). From the same database, we obtained data on Population (in millions) and data on the CPI (with 2005 as the

\footnotetext{
${ }^{9}$ The CRS database is maintained by the Development Assistance Committee (DAC), which is part of the OECD's Development Co-operation Directorate (DCD).
} 
base year). Data on GDP (in constant 2005 US\$), which is needed in order to calculate market potentials, also comes from the WDI database. Data on bilateral distances - which is needed in order to calculate market potentials - is taken from CEPII $(2013 \mathrm{a} / \mathrm{b})$. Data on government effectiveness $(G E)$ comes from the Worldwide Governance Indicators (WGI) project (World Bank, 2013b). $G E$ indicates the strength of governance performance. Finally, data on the strength of legal rights index $(S O L R)$, which "measures the degree to which (...) laws protect the rights of borrowers and lenders and thus facilitate lending" (World Bank, 2013a), comes from the WDI database (World Bank, 2013a). The SOLR dataset is not part of our baseline model, but is used as an alternative to the government effectiveness $(G E)$ index in certain regressions.

Table 1 contains summary statistics of the main variables used in the empirical analysis. The first part of Table 1 contains summary statistics for the AfT proxies. Proxies for "total" AfT disbursements (D_TOTAL) are calculated as the sum of the 3 sub-categories of AfT considered.

Table 1: Summary statistics for the AfT-proxies, dependent variable and controls

\begin{tabular}{|l|l|l|l|l|l|}
\hline $\begin{array}{l}\text { Target } \\
\text { Variables }\end{array}$ & Obs & Mean & Std. Dev. & Min & Max \\
\hline Disbursements of AfT & 1204 & 3.360 & 15.781 & 0.000 & 403.724 \\
\hline D_TPR & 1391 & 84.549 & 185.843 & .003 & 2107.355 \\
\hline D_EI & 1421 & 63.534 & 114.457 & .0031 & 1179.496 \\
\hline D_BPC & 1425 & 148.727 & 288.606 & 0.003 & 3042.281 \\
\hline D_TOTAL & 742 & 70.240 & 122.008 & 0.00 & 1066.810 \\
\hline D_GBS & & & & & \\
\hline $\begin{array}{l}\text { Dependent } \\
\text { Variable }\end{array}$ & 1228 & 29051.210 & 108752.000 & 15.785 & 1677840 \\
\hline Exports & & & & & \\
\hline $\begin{array}{l}\text { Control } \\
\text { Variables }\end{array}$ & 1788 & 35.552 & 142.991 & 0.009 & 1344.130 \\
\hline Population & 1728 & 7907.086 & 3447.210 & 3291.178 & 24758.810 \\
\hline MP1 & 1628 & -0.464 & 0.679 & -2.454 & 1.590 \\
\hline GE & 1562 & 296.858 & 7418.968 & 0.288 & 293318 \\
\hline CPI & 1728 & 558266.1 & 103877 & 354308.8 & 966380.7 \\
\hline MP2 & 1728 & 4.273 & 8.793 & 0.329 & 93.052 \\
\hline MP3 & 1075 & 4.805 & 2.342 & 0 & 10 \\
\hline SOLR & $159 a 1 c u l a t e d ~$ & & & \\
\hline
\end{tabular}

Notes: D TOTAL is calculated as the sum of D TPR, D EI and, D BPC. When data on some of the three components was missing, D_TOTAL was calculated as the sum of the others. D_TOTAL values are in constant 2011 US\$ millions. Exports $=$ exports of goods and services (constant 2005 US\$ millions). Population = total population (in millions). $M P 1=$ market potential (with simple distances). $G E=$ government effectiveness $(-2.5=$ weak to $2.5=$ strong government performance). $C P I=$ consumer price index $(2005=100) . M P 2 / 3=$ market 
potential $2 / 3$ (with square root/squared distances). SOLR $=$ strength of legal rights index $(0=$ weak to $10=$ strong).

Below, we discuss the AfT-proxies in detail. First, note that the number of observations for AfT commitments is significantly higher than that for AfT disbursements (see Table A.6). This is primarily due to the fact that data on disbursements is entirely missing prior to 2002 (in our case, for 2000 and for 2001).

Second, the average size of AfT commitments and disbursements is notable (see Table A3). The mean value of AfT commitments for economic infrastructure $\left(C_{-} E I\right)$, which is the average value per country and year, is about US\$ 84.5 million. The fact that AfT is quite sizeable can best be seen when expressed relative to GDP. The ratio of the sum of all AfT proxies to GDP has a mean value of $2.7 \%$ for commitments and $1.5 \%$ for disbursements. Third, AfT commitments tend to be larger and more volatile than AfT disbursements. As can be seen in Table A.6, mean commitments are strikingly larger than mean disbursements. The correlation coefficient between total commitments $\left(C_{-}\right.$TOTAL $)$and total disbursements $\left(D_{-}\right.$TOTAL) is about $81 \%$.

Figure 1 shows a Kernel density function for $D_{-}$TOTAL. The figure indicates that the estimated distribution is skewed to the right with most countries receiving relatively little AfT, with just a few receiving significantly more. ${ }^{10}$ This fact is also illustrated in Table A.7, which shows the percentiles for the distribution of D_TOTAL. While the median value of total AfT disbursements is smaller than US\$ 32 million, the $99^{\text {th }}$ percentile is 50 times as large.

Figure 1. Kernel density estimate for total AfT disbursements

${ }^{10}$ That "[AfT] (...) is relatively concentrated" is also discussed in OECD/WTO (2011: 14). 


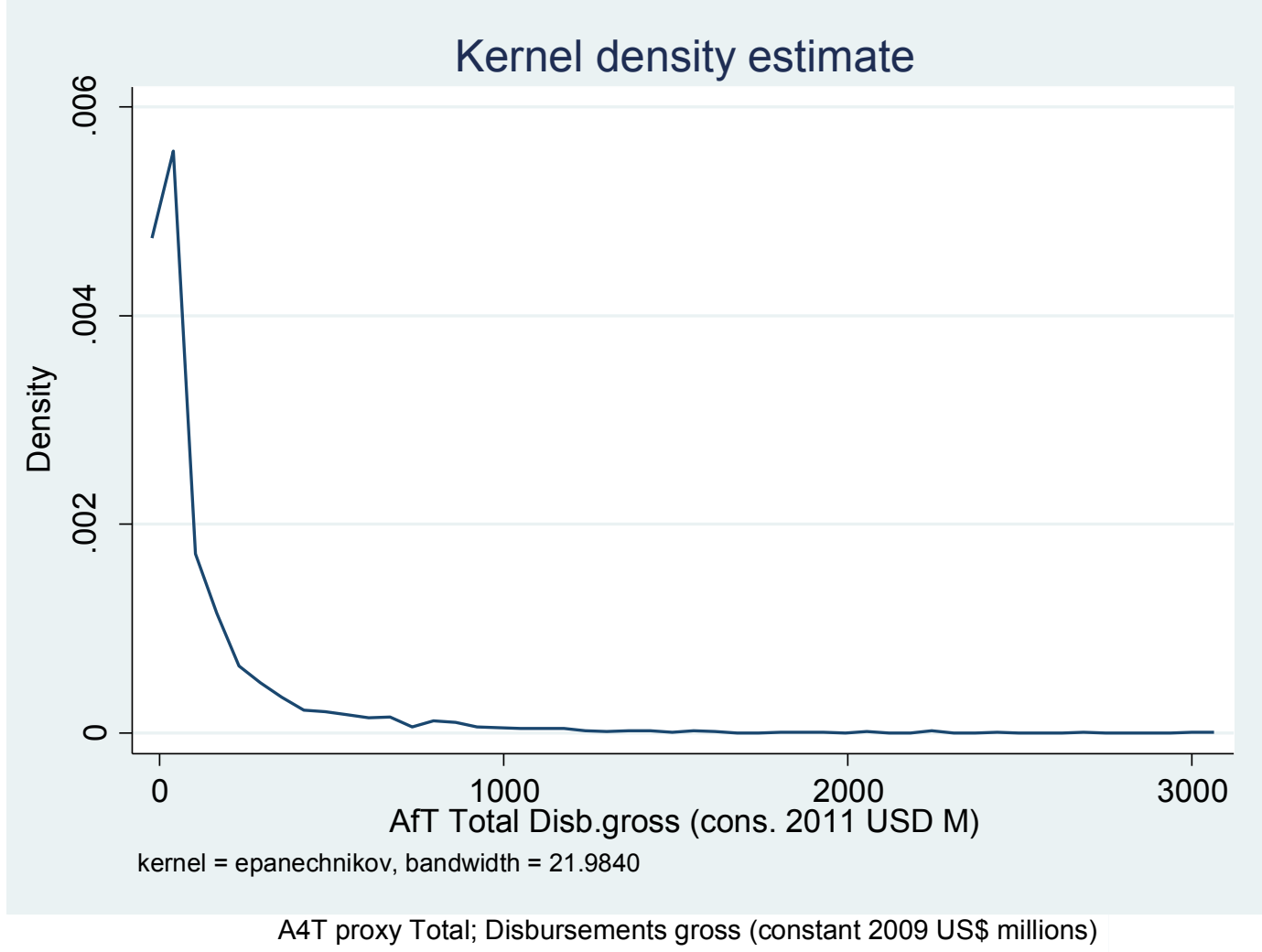

Source: Own illustration based on own calculations. Data: OECD (2013a). Notes: Kernel = Epanechnikov; bandwidth $=53.3482$.

The second part of Table 1 contains the summary statistics of the dependent and control variables. It is worth noting here that the CPI (base year: 2005) ranges between 0.288 and 293318. The outliers belong to Zimbabwe, which recently experienced a period of hyperinflation (see, e.g., Hanke, 2008). The outliers inflate the standard deviation and the mean, and are therefore eliminated from the final regression. When excluding the observations for Zimbabwe, the mean (standard deviation) of the CPI drops from over $300(7,800)$ to around 100 (25). The CPI is seen as a measure of price competitiveness and replaces the real exchange rate which has many missing data points (see Calì and te Velde, 2011). We expect an increase in consumer prices to hinder price competitiveness in the recipient country and to have a negative sign.

After having presented the empirical model in Section 2; and data and descriptive statistics in this section, in the following section we discuss the results of the regression analysis. 


\subsection{Main Results}

In this section, we estimate the model specified in Section 2 by using data for 162 countries over the period 2002 to 2011 (for AfT disbursements) and applying a number of different estimation techniques: (i) a (pooled) OLS regression with time fixed effects and regional dummy variables (as a benchmark, see Table 2, col. 1 and 2), (ii) a fixed effects OLS regression, see Table 2, col. 3 and 4 (iii) a GMM dynamic panel-data regression, see Table 2, col. 5 and 6 and (iv) a panel quantile approach (see Tables 3 and 4). The choice between using fixed or random effects ultimately depends on our assumption about the correlation between the unobserved effect and the explanatory variables (Wooldridge, 2001). The Hausman test indicates a rejection of the null hypothesis (the unobserved effects are uncorrelated with the explanatory variables), indicating that fixed effects should be used. ${ }^{11}$

We also perform some regression diagnostics. For the OLS-regressions, the residuals are close to normal and homoscedastic. Furthermore, there is no multicollinearity problem. In the fixed effects models, heteroscedasticity and autocorrelation were present. Consequently, we use standard error estimates that are robust to these disturbances (Hoechle, 2007: 285). In col. 5 and 6 we account for dynamics and for the endogeneity of the AfT and lagged exports relaying on internal instruments. We now discuss our results in some detail.

Table 2: Baseline regression results. Dependent variable: In (exports of goods and services in constant 2005 US\$ millions). Key explanatory variables: log AfT disbursements

\begin{tabular}{|c|c|c|c|c|c|c|}
\hline & $\begin{array}{c}(1) \\
\text { M1(OLS) }\end{array}$ & $\begin{array}{c}(2) \\
\text { M2(OLS) }\end{array}$ & $\begin{array}{c}\text { (3) } \\
\text { M3(FE) }\end{array}$ & $\begin{array}{c}(4) \\
\text { M4(FE) }\end{array}$ & $\begin{array}{c}(5) \\
\text { M5(GMM) }\end{array}$ & $\begin{array}{c}(6) \\
\text { M6(GMM) }\end{array}$ \\
\hline $\operatorname{lnD}$ TOTAL & $\begin{array}{c}0.502^{* * *} \\
(0.17)\end{array}$ & & $\begin{array}{c}-0.0170 \\
(0.02)\end{array}$ & & $\begin{array}{l}0.145 \\
(0.13)\end{array}$ & \\
\hline $\operatorname{lnD} \mathrm{TPR}$ & & $\begin{array}{c}0.159 * * * \\
(0.05)\end{array}$ & & $\begin{array}{c}0.00100 \\
(0.01)\end{array}$ & & $\begin{array}{c}0.00200 \\
(0.00)\end{array}$ \\
\hline $\operatorname{lnD} \mathrm{EI}$ & & -0.0690 & & -0.00700 & & -0.00200 \\
\hline
\end{tabular}

\footnotetext{
${ }^{11}$ We assume that the requirements and assumptions of the Hausman test are fulfilled. Any discussion of these issues falls outside the scope of this paper.
} 


\begin{tabular}{|c|c|c|c|c|c|c|}
\hline & & $(0.09)$ & & $(0.01)$ & & $(0.01)$ \\
\hline \multirow{2}{*}{$\operatorname{lnD} \mathrm{BPC}$} & & $0.451 * * *$ & & 0.00200 & & 0.0140 \\
\hline & & $(0.14)$ & & $(0.02)$ & & $(0.01)$ \\
\hline \multirow[t]{2}{*}{$\operatorname{lnD}$ GBS } & $-0.235 * * *$ & $-0.180 * * *$ & $-0.008^{*}$ & $-0.011 * *$ & -0.0270 & -0.00400 \\
\hline & $(0.05)$ & $(0.05)$ & $(0.00)$ & $(0.00)$ & $(0.04)$ & $(0.00)$ \\
\hline \multirow[t]{2}{*}{ Population } & $0.003 * * *$ & $0.003 * * *$ & $0.006 * *$ & $0.005 * *$ & 0.00400 & 0.00100 \\
\hline & $(0.00)$ & $(0.00)$ & $(0.00)$ & $(0.00)$ & $(0.01)$ & $(0.00)$ \\
\hline \multirow[t]{2}{*}{$\ln \mathrm{MP} 1$} & -0.259 & -0.138 & 0.380 & 0.0930 & 0.159 & $0.884 * *$ \\
\hline & $(0.60)$ & $(0.54)$ & $(1.05)$ & $(0.99)$ & $(0.84)$ & $(0.43)$ \\
\hline \multirow[t]{2}{*}{ GE } & $0.692 * *$ & $0.682 * *$ & 0.0620 & 0.0650 & -0.0320 & 0.00100 \\
\hline & $(0.30)$ & $(0.28)$ & $(0.11)$ & $(0.12)$ & $(0.09)$ & $(0.06)$ \\
\hline \multirow{2}{*}{$\ln \mathrm{CPI}$} & -0.0590 & -0.127 & -0.00800 & -0.0240 & 0.0320 & -0.0260 \\
\hline & $(0.21)$ & $(0.23)$ & $(0.07)$ & $(0.06)$ & $(0.09)$ & $(0.02)$ \\
\hline \multirow[t]{2}{*}{ Africa Dummy } & -0.827 & -0.212 & & & & \\
\hline & $(0.68)$ & $(0.59)$ & & & & \\
\hline \multirow{2}{*}{ America Dummy } & 0.114 & 0.411 & & & & \\
\hline & $(0.66)$ & $(0.56)$ & & & & \\
\hline \multirow[t]{2}{*}{ Asia Dummy } & -0.197 & 0.177 & & & & \\
\hline & $(0.58)$ & $(0.48)$ & & & & \\
\hline \multirow[t]{2}{*}{ Pacific Dummy } & $-2.611 * * *$ & $-2.084 * * *$ & & & & \\
\hline & $(0.92)$ & $(0.79)$ & & & & \\
\hline \multirow[t]{2}{*}{ ln Exports (t-1) } & & & & & $0.681 * * *$ & $0.599 * * *$ \\
\hline & & & & & $(0.17)$ & $(0.14)$ \\
\hline \multirow[t]{2}{*}{ Constant } & 5.548 & 4.176 & 4.502 & 6.944 & & \\
\hline & (6.34) & $(5.51)$ & $(9.32)$ & $(8.76)$ & & \\
\hline Nobs & 509 & 451 & 509 & 451 & 284 & 398 \\
\hline $\mathrm{R} 2$ & 0.455 & 0.516 & 0.587 & 0.616 & 0.628 & 0.787 \\
\hline $\mathrm{R} 2 \mathrm{a}$ & 0.433 & 0.492 & 0.574 & 0.601 & 0.511 & 0.729 \\
\hline
\end{tabular}

In columns (1) and (2), we run OLS regressions. In (1), we regress the log of exports of goods and services on the log of "total" AfT disbursements while controlling for Population size, the $\log$ of $M P 1$, government effectiveness and the $\log$ of the CPI. Year and region dummies are included. In (2), we make use of our three "defined" aid categories (three AfT categories), use (untargeted) aid for GBS as a control variable and regress the log of exports on the logs of aid disbursed to TPR, to EI, to BPC and to GBS and on our baseline controls. In column (1), the coefficient of the log of "total" AfT disbursements is positive and statistically significant. Hence, the results of the (pooled) OLS regression suggest that larger "total" AfT disbursements are, ceteris paribus and on average, associated with higher exports of goods and services. The coefficients of our logged AfT proxies in (2) are statistically significant and positive for aid disbursed to TPR and for aid to boost building productive capacity; and negative for GBS (used for contrasting the results obtained for AfT). The coefficient of aid disbursed for GBS is plausible when recipient countries do not stress trade development. Overall, the 
coefficients of our baseline controls in (1) and (2) have the expected signs except for the log of market potential (which has a negative but statistically insignificant coefficient). The coefficients of Population and GE are statistically significant at the $1 \%$ level. To conclude, most coefficients - except for the coefficient of (the $\log$ of) MP1 - have the expected signs. "Total" AfT disbursements and aid disbursed to TPR and BPC seem to be effective. The effect of aid disbursed to EI cannot be distinguished from zero and aid disbursed to GBS may even be counter-productive. However, these findings should be approached with caution since we did not fully control for unobserved (time-invariant) heterogeneity in these regressions given that we use regional fixed effects but not country fixed effects.

Columns (3) and (4) in Table 2 contain the results of estimating (country) fixed effects regressions and robust standard errors. Using this technique, which controls for countryspecific and time-invariant unobserved heterogeneity, the results change dramatically and total AfT and its sub-components become insignificant. Population, Market Potential and the CPI have the expected signs, but only the former is statistically significant.

In columns (5) and (6) of Table 2, we use a dynamic-panel GMM regression and control for endogeneity using lagged values for aid and lagged exports. The estimates are efficient for arbitrary heteroskedasticity and autocorrelation and statistics are robust to heteroskedasticity and autocorrelation. Neither total AfT nor its three sub-components have a significant impact on recipient countries' exports. In column (6) the control variable government efficiency (GE) has a significant positive impact on exports. We interpret the insignificant coefficient of total AfT and of its sub-components as an indication that on average (considering the mean) AfT and AfT_TPR, AfT_EI and AfT_BPC do not affect the average exporter. This of course does not exclude the possibility that AfT might have a different impact on small, medium and large exports.

We also experimented with alternative controls. We substituted the log of $M P 1$ with the logs of $M P 2$ and $M P 3$, respectively. The coefficient of market potential was positive and not statistically significant when using fixed effects, irrespective of the size of the distance weighting parameter. There is no substantial change in the size of all other coefficients and the 
coefficient of $G E$ stays statistically insignificant. Finally, we use $S O L R$ instead of $G E$ to control for institutional quality. This leaves all other coefficients almost unaffected. The coefficient of SOLR has a positive sign, as expected, but is statistically insignificant.

In short, the pooled OLS regressions indicate that AfT is (partly) effective but the FE regression results (which control for country heterogeneity, autocorrelation and in one version for endogeneity) show that "total" AfT disbursements are, on average, ineffective. The subcategories of AfT disbursements (TPR, EI and BPC) seem to be ineffective as well. It is also worth mentioning that coefficients do change slightly when we run the regressions shown augmented with AfT disbursements lagged by two years ${ }^{12}$. In particular, in the fixed effects estimation (Model 4), aid to building productive capacity has a coefficient of 0.04 , which is statistically significant at the $10 \%$ level and in the GMM estimation (Model 6), aid to economic infrastructure is also statistically significant at the $10 \%$ level with a coefficient of 0.016 .

Given the results obtained so far, we conclude that a more differentiated approach is warranted, as potentially the effectiveness of AfT depends on the level of exports and thus the quantile of the export distribution. Below, we present the impact of AfT on exports using a panel-quantile framework. For the panel quantile regressions, we have to transform the dependent variable as no ready-made estimation routine is available. First, we control for country heterogeneity by subtracting the impact of country fixed effects from the log of exports. Second, we control for time-specific events by utilizing time-fixed effects.

As can be seen in Table 3, total AfT is not effective at the lower end of the export distribution, namely at the 0.10 and 0.25 quantiles. However, it is statistically significant above the $0.35^{13}$ level, and also in the $0.50,0.75$ and 0.90 quantiles. Non-targeted aid (aid for global budget support), in contrast, is insignificant at the 0.10 quantile and even has a negative impact in the $0.25,0.50$ and 0.75 quantiles. Population, market potential and government effectiveness

\footnotetext{
${ }^{12}$ We also run all regressions presented thus far with commitments instead of disbursements. Results, which are available upon request, are far from satisfactory. When running the regressions with commitments (lagged by one and two years), the coefficients of the vast majority of AfT proxies are statistically insignificant.

${ }^{13}$ The mean value of AfT disbursements is US\$ 147 million per country and year and the median value of AfT stands at US\$ 32 million US\$ per country and year.
} 
have the expected positive sign. Inflation has an ambiguous impact on exports as minor inflation might send out a positive signal and enhance production (positive sign), but higher rates of inflation might confuse producers and reduce the competitiveness of exporters (negative sign).

Table 3: Panel-quantile regression results for total AfT

\begin{tabular}{|c|c|c|c|c|c|c|}
\hline & $\begin{array}{c}(1) \\
M 1(Q .1) \\
\end{array}$ & $\begin{array}{c}(2) \\
M 2(Q .25) \\
\end{array}$ & $\begin{array}{c}(3) \\
M 3(Q .35) \\
\end{array}$ & $\begin{array}{c}(4) \\
M 4(Q .5) \\
\end{array}$ & $\begin{array}{c}(5) \\
M 5(Q .75) \\
\end{array}$ & $\begin{array}{c}(6) \\
\text { M6(Q.90) }\end{array}$ \\
\hline lnD TOTAL & $\begin{array}{c}-0.00900 \\
(0.01)\end{array}$ & $\begin{array}{c}0.0100 \\
(0.01)\end{array}$ & $\begin{array}{c}0.016^{* * * *} \\
(0.01)\end{array}$ & $\begin{array}{c}0.023 * * * \\
(0.00)\end{array}$ & $\begin{array}{c}0.037 * * * \\
(0.01)\end{array}$ & $\begin{array}{c}0.036 * * * \\
(0.01)\end{array}$ \\
\hline $\operatorname{lnD} \mathrm{GBS}$ & $\begin{array}{c}-0.00100 \\
(0.01)\end{array}$ & $\begin{array}{c}-0.009^{*} \\
(0.01)\end{array}$ & $\begin{array}{c}-0.009 * * \\
(0.00)\end{array}$ & $\begin{array}{c}-0.00600 \\
(0.00)\end{array}$ & $\begin{array}{c}-0.007 * * \\
(0.00)\end{array}$ & $\begin{array}{c}-0.00500 \\
(0.00)\end{array}$ \\
\hline Population & $\begin{array}{c}0.004 * * * \\
(0.00)\end{array}$ & $\begin{array}{c}0.004 * * * \\
(0.00)\end{array}$ & $\begin{array}{c}0.004 * * * \\
(0.00)\end{array}$ & $\begin{array}{c}0.004 * * * \\
(0.00)\end{array}$ & $\begin{array}{c}0.004 * * * \\
(0.00)\end{array}$ & $\begin{array}{c}0.003 * * * \\
(0.00)\end{array}$ \\
\hline $\ln \mathrm{MP} 1$ & $\begin{array}{c}0.902 * * * \\
(0.03)\end{array}$ & $\begin{array}{c}0.887 * * * \\
(0.02)\end{array}$ & $\begin{array}{c}0.875^{* * *} * \\
(0.02)\end{array}$ & $\begin{array}{c}0.840 * * * \\
(0.01)\end{array}$ & $\begin{array}{c}0.864 * * * \\
(0.02)\end{array}$ & $\begin{array}{c}0.829 * * * \\
(0.04)\end{array}$ \\
\hline GE & $\begin{array}{c}0.111 * * * \\
(0.03)\end{array}$ & $\begin{array}{c}0.074 * * * \\
(0.02)\end{array}$ & $\begin{array}{c}0.057 * * * \\
(0.02)\end{array}$ & $\begin{array}{c}0.055^{* * * *} \\
(0.01)\end{array}$ & $\begin{array}{c}0.034 * * \\
(0.02)\end{array}$ & $\begin{array}{l}0.045^{*} \\
(0.03)\end{array}$ \\
\hline $\ln \mathrm{CPI}$ & $\begin{array}{c}0.0330 \\
(0.04)\end{array}$ & $\begin{array}{c}-0.0150 \\
(0.03)\end{array}$ & $\begin{array}{c}-0.0320 \\
(0.03)\end{array}$ & $\begin{array}{c}-0.0430 \\
(0.03)\end{array}$ & $\begin{array}{c}0.0700 \\
(0.16)\end{array}$ & $\begin{array}{c}-0.088 * * * \\
(0.02)\end{array}$ \\
\hline Constant & $\begin{array}{l}-0.275 \\
(0.46)\end{array}$ & $\begin{array}{c}-0.0170 \\
(0.32)\end{array}$ & $\begin{array}{c}0.0460 \\
(0.23)\end{array}$ & $\begin{array}{l}0.277 \\
(0.25)\end{array}$ & $\begin{array}{l}-0.674 \\
(0.82)\end{array}$ & $\begin{array}{l}0.437 \\
(0.47)\end{array}$ \\
\hline $\begin{array}{l}\text { Nobs } \\
\text { R2 a }\end{array}$ & $\begin{array}{c}332 \\
0.886\end{array}$ & $\begin{array}{c}332 \\
0.888\end{array}$ & $\begin{array}{c}332 \\
0.891\end{array}$ & $\begin{array}{c}332 \\
0.893\end{array}$ & $\begin{array}{c}332 \\
0.889\end{array}$ & $\begin{array}{c}332 \\
0.880\end{array}$ \\
\hline
\end{tabular}

Notes: Dependent variable: In (Exports of goods and services in constant 2005 US\$ millions). The FE used to transform exports are from the fixed effect regression. Key explanatory variable: total AfT disbursements. Time fixed effects are included but are not reported to save space. Robust standard errors are in brackets. ${ }^{*} p<0.10,{ }^{* *}$ $p<0.05,{ }^{* * *} p<0.01$

Figure 2 summarises the results and shows confident bands obtained by bootstrapping the standard errors, using 500 repetitions. The main reason for bootstrap is that we are using estimates of the fixed effects from a first step regression in the quantile regressions. The main difference with respect to the standard errors shown in Table 3 is that in general, they are slightly smaller in magnitude and as a result the confident intervals are narrower than the equivalents that might be obtained from Table 3. 
Figure 2. Panel-quantile regression results for total AfT

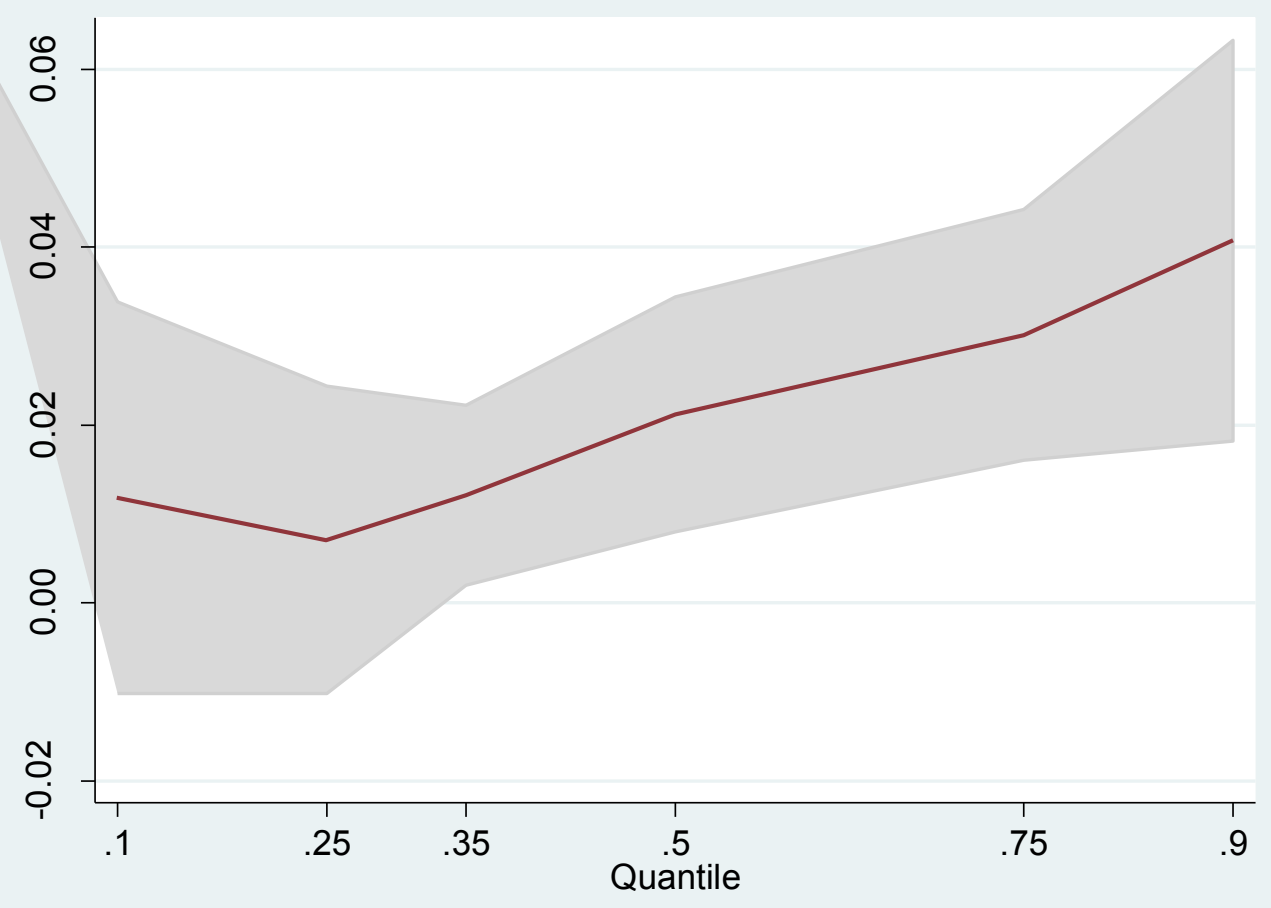

Our main findings can be summarised as follows. The regression results indicate that "total" AfT disbursements are effective only for countries with a level of exports above the 0.35 quantile. A doubling of AfT increases exports by about $1.6 \%$ at the 0.35 quantile of the export distribution over a time span of 10 years (2002-2011 period) and by about 3.6 at the 0.90 quantile. This effect, translated into monetary returns means that an increase of 1 USD of total AfT will lead to an increase in exports of 1.68 USD (4.15 USD) for an exporter at the median of the distribution of exports (at the 0.90 quantile). These results are in keeping with the findings of other recent literature.

Assuming that the result could also vary by type of AfT, we now examine how certain sub-categories of AfT can help exporters at different quantiles. For instance, aid for trade policy and regulation can improve insufficient knowledge on how to develop an adequate trade policy concept or to participate in trade negotiations; aid for economic infrastructure can supplement insufficient means in recipient countries to invest in economic infrastructure and aid for building 
productive capacity can counteract insufficient means and knowledge related to underdeveloped productive capacity in agriculture, industry and mining.

As to the efficiency of specific AfT categories, we find aid for trade policy and regulation is not effective in any quantile. Aid for economic infrastructure is only effective in the lowest $(0.10)$ quantile but the significant level is slightly higher than 0.10 . However, aid for building productive capacity is effective in all quantiles of the export distribution, except in the 0.10 , with the largest impact occurring in the 0.90 quantile. Aid for global budget support, an untargeted aid component, is detrimental to exports at the $0.25,0.35$ and 0.50 quantiles, most probably due to disincentives to production and export.

Table 4. Panel-quantile regression results for specific types of aid

\begin{tabular}{|c|c|c|c|c|c|c|}
\hline & $\begin{array}{c}(1) \\
M 1(Q .1) \\
\end{array}$ & $\begin{array}{c}(2) \\
M 2(Q .25) \\
\end{array}$ & $\begin{array}{c}(3) \\
M 3(Q .35) \\
\end{array}$ & $\begin{array}{c}(4) \\
M 4(Q .5) \\
\end{array}$ & $\begin{array}{c}(5) \\
\text { M5(Q.75) } \\
\end{array}$ & $\begin{array}{c}(6) \\
M 6(Q .90) \\
\end{array}$ \\
\hline $\operatorname{lnD} \mathrm{TPR}$ & $\begin{array}{c}-0.0110 \\
(0.01)\end{array}$ & $\begin{array}{c}-0.00800 \\
(0.01)\end{array}$ & $\begin{array}{c}-0.00600 \\
(0.01)\end{array}$ & $\begin{array}{c}-0.00100 \\
(0.01)\end{array}$ & $\begin{array}{c}-0.0100 \\
(0.01)\end{array}$ & $\begin{array}{c}-0.0110 \\
(0.01)\end{array}$ \\
\hline $\ln \mathrm{D} E I$ & $\begin{array}{c}0.0270^{*} \\
(0.018)\end{array}$ & $\begin{array}{c}0.00200 \\
(0.007)\end{array}$ & $\begin{array}{c}0.00700 \\
(0.01)\end{array}$ & $\begin{array}{c}0.0100 \\
(0.01)\end{array}$ & $\begin{array}{c}0.00600 \\
(0.01)\end{array}$ & $\begin{array}{c}-0.00500 \\
(0.01)\end{array}$ \\
\hline $\ln \mathrm{D} B P C$ & $\begin{array}{c}0.0110 \\
(0.03)\end{array}$ & $\begin{array}{c}0.045^{* * * *} \\
(0.01)\end{array}$ & $\begin{array}{c}0.041 * * * \\
(0.01)\end{array}$ & $\begin{array}{c}0.038 * * * \\
(0.01)\end{array}$ & $\begin{array}{c}0.050 * * * \\
(0.01)\end{array}$ & $\begin{array}{c}0.065 * * * \\
(0.01)\end{array}$ \\
\hline $\operatorname{lnD} \mathrm{GBS}$ & $\begin{array}{c}-0.00900 \\
(0.01)\end{array}$ & $\begin{array}{c}-0.011 * * * \\
(0.00)\end{array}$ & $\begin{array}{c}-0.010^{* * *} \\
(0.00)\end{array}$ & $\begin{array}{c}-0.009 * * * \\
(0.00)\end{array}$ & $\begin{array}{c}-0.00200 \\
(0.00)\end{array}$ & $\begin{array}{c}0.00300 \\
(0.00)\end{array}$ \\
\hline Population & $\begin{array}{c}0.003^{* * *} * \\
(0.00)\end{array}$ & $\begin{array}{c}0.003^{* * *} \\
(0.00)\end{array}$ & $\begin{array}{c}0.003 * * * \\
(0.00)\end{array}$ & $\begin{array}{c}0.003^{* * *} * \\
(0.00)\end{array}$ & $\begin{array}{c}0.003 * * * \\
(0.00)\end{array}$ & $\begin{array}{c}0.002 * * * \\
(0.00)\end{array}$ \\
\hline $\ln$ MP1 & $\begin{array}{c}0.956^{* * *} \\
(0.06)\end{array}$ & $\begin{array}{c}0.942 * * * \\
(0.02)\end{array}$ & $\begin{array}{c}0.924 * * * \\
(0.02)\end{array}$ & $\begin{array}{c}0.915^{* * *} \\
(0.01)\end{array}$ & $\begin{array}{c}0.907 * * * \\
(0.03)\end{array}$ & $\begin{array}{c}0.899 * * * \\
(0.03)\end{array}$ \\
\hline GE & $\begin{array}{c}0.123^{* * *} * \\
(0.05)\end{array}$ & $\begin{array}{c}0.091 * * * \\
(0.01)\end{array}$ & $\begin{array}{c}0.088 * * * \\
(0.02)\end{array}$ & $\begin{array}{c}0.073 * * * \\
(0.02)\end{array}$ & $\begin{array}{c}0.073 * * * \\
(0.02)\end{array}$ & $\begin{array}{c}0.0390 \\
(0.03)\end{array}$ \\
\hline $\ln \mathrm{CPI}$ & $\begin{array}{c}0.0360 \\
(0.05)\end{array}$ & $\begin{array}{c}-0.0290 \\
(0.02)\end{array}$ & $\begin{array}{c}-0.037^{*} \\
(0.02)\end{array}$ & $\begin{array}{c}-0.056^{* *} \\
(0.02)\end{array}$ & $\begin{array}{c}-0.074 * * * \\
(0.02)\end{array}$ & $\begin{array}{c}-0.106^{* * *} \\
(0.02)\end{array}$ \\
\hline Constant & $\begin{array}{c}-1.331 * * \\
(0.64)\end{array}$ & $\begin{array}{c}-1.014 * * * \\
(0.25)\end{array}$ & $\begin{array}{c}-0.844 * * * \\
(0.23)\end{array}$ & $\begin{array}{c}-0.697 * * * \\
(0.19)\end{array}$ & $\begin{array}{c}-0.628^{* *} \\
(0.27)\end{array}$ & $\begin{array}{l}-0.417 \\
(0.28)\end{array}$ \\
\hline $\begin{array}{l}\text { Nobs } \\
\text { R2 a }\end{array}$ & $\begin{array}{c}276 \\
0.883\end{array}$ & $\begin{array}{c}276 \\
0.890\end{array}$ & $\begin{array}{c}276 \\
0.892\end{array}$ & $\begin{array}{c}276 \\
0.889\end{array}$ & $\begin{array}{c}276 \\
0.890\end{array}$ & $\begin{array}{c}276 \\
0.875\end{array}$ \\
\hline
\end{tabular}

Notes: Dependent variable: In (Exports of goods and services in constant 2005 US\$ millions). The FE used to transform exports are from the fixed effect regression. Key explanatory variables: 3 types of logged AfT disbursements. Robust standard errors in parentheses. Time fixed effects were included but are not reported to save space. $* p<0.10, * * p<0.05, * * * p<0.01$. 
Figure 3 summarises the results and shows confident bands obtained by bootstrapping the standard errors using 500 repetitions, for the same reason as explained above.

Figure 3. Panel-quantile regression results for AfT sub-categories
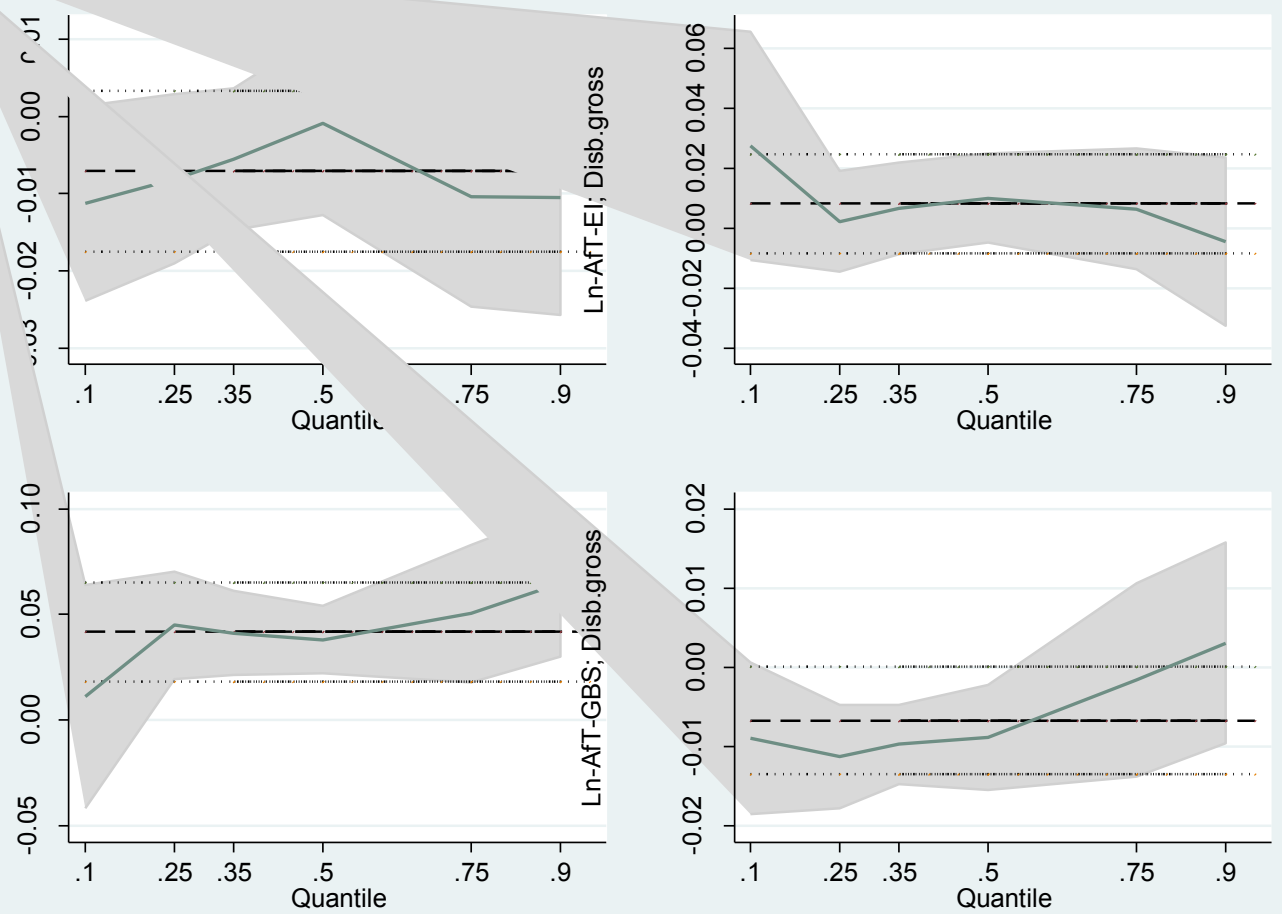

\subsection{Robustness}

In this section we present a number of robustness checks in order to validate our results. First, following Hühne et al. (2014), we alternatively control for the possible endogeneity of AfT by lagging the series two periods in the quantile regressions. In economic terms, this means that AfT today affects exports after two years. The delay of two years could be explained by a reaction lag concerning the production and export of goods and services. The results can be seen in Table A.8. The main differences with results reported in Tables 3 and 4, in which the levels of AfT were used are that Total AfT is already statistically significant at the 0.25 quantile instead of at the 0.35 , and that in the quantile regression by AfT subcategories, not only is aid for 
building productive capacity positive and statistically significant, but so is aid for economic infrastructure at the median value of exports and also at the 0.75 quantile.

Calì and te Velde (2011) tackled the endogeneity problem by employing instrumental variable estimators. The instruments used for AfT are 'respect for civil liberties and human rights' and the 'affinity of nations' (political proximity to the US, Japan, UK or France). Those authors found that controlling for endogeneity changes the size of the coefficients, but the main conclusion regarding AfT effectiveness remains the same.

Second, to tackle the problem of "zero"-exports, we applied a Heckman two-step procedure. We tried to identify a reasonable selection variable, however, with country-fixed effects no other sensible variable qualified as a selection variable. In a common intercept model, the status of legal rights (SOLR) could qualify as a selection variable but only with a confidence level of $82 \%$. As an alternative, we applied Pseudo Maximum Likelihood estimation (PPML). The results for the different AfT components for the model without and with country fixed effects are similar to the ones found in Table 2 (see Table A.9).

Third, controlling for missing values in the AfT variables was not possible either as generating an AfT-dummy variable (i.e. replacing the "na" values by zeros and setting the positive AfT-values to "1") led to perfect multicollinearity between the AfT-variables and the AfT-dummy. However, according to Calì and te Velde (2011), missing values for the Aft variables are not an imminent problem. Most missing values cannot be observed for exports.

Finally, we also estimated similar models without the control aid for general budget support. The main results obtained for target AfT variables remained the same.

Summarising, the estimation of the impact of AfT on different quantiles of the export distribution seems warranted as only this procedure takes into account the heterogeneity of impacts along the distribution of exports and produces stable results.

\section{Conclusions}


It is widely acknowledged that one of the main objectives of AfT is to promote exports of goods and services. Given said aim, this paper examines the extent to which AfT is effective in promoting trade, particularly in countries with a weak export capacity. To this end, we analyse whether AfT and its different components are associated with higher exports of goods and services, quantify the effects and examine whether these effects depend on the conditional distribution of exports and the time frame studied.

We find that AfT-disbursements (also of different types) are not effective in conditional mean panel regression models (standard regression models) with country fixed effects. Using panel quantile regressions we find that total AfT disbursements are effective at the 0.35 quantile of the distribution of exports, where they promote exports of goods and services. However, AfT is not effective at the lower tails ( 0.1 and 0.25 quantiles). All things being equal, a $100 \%$ increase of "total" AfT disbursements is associated with an increase in exports of around 2-3\% depending on the quantile and taken over a 10-year time period. On an annual basis, this would leave the recipient countries with a $0.2 \%$ increase in exports as a result of AfT.

We also find that specific types of AfT are effective to differing extents. We find evidence that AfT to support trade policy and regulation is not effective in any quantile of the export distribution, but this type of AfT represents less than 5\% of total AfT. Aid disbursed to building production capacity (BPC) is effective in almost all quantiles of the export distribution. Doubling BPC leads to an increase in exports of around 4.5-6.5\%. However, it is worth mentioning that this sub-type of AfT reaches maximum impact in the 0.90 quantile. This could mean that smaller exporters with a more reduced basis in knowledge and experience profit less from AfT for BPC. For instance, this type of aid is sector-specific and can take the form of technical assistance (training provided by experts) and/or transfers in the form of grants and loans. Effectiveness of aid for EI is effective at the 0.10 quantile when using. Doubling infrastructure-related aid in this quantile leads to a $0.27 \%$ increase of exports. Therefore, an increase of AfT for economic infrastructure would be especially helpful to less mature 
exporters. In comparison, aid disbursed under GBS is generally not associated with higher exports. It seems to be rather counter-productive, even showing a negative effect on exports, and hence apparently not improving the business environment.

In conclusion and in comparison with other studies, we find that aid disbursed to TPR is a category of AfT that seems not to be effective irrespective of the exported amount. This result is not in line with the findings of Hühne et al. (2014) whose findings indicate that AfT to TPR has the strongest impact. According to our results, aid for building productive capacity (BPC) is effective in almost all quantiles of the export distribution and also has the largest impact on exports. Furthermore, our results indicate that certain types of AfT, such as AfT for economic infrastructure, which is considered as generally effective by Calì and te Velde (2011), is only effective at the lowest quantile of the distribution of exports.

Further research should examine the topic of AfT effectiveness in greater detail. To date, we know that some types of AfT are effective in promoting exports, whereas others are not so effective. An important focus of further research should be to examine why some types of AfT are less effective. Additionally, the relationship between AfT and a number of social outcomes (such as poverty rates) also warrant further examination, as increased trade is only a means to an end and not an end in itself. 


\section{References}

Adhikari R (2011). Evaluating Aid for Trade Effectiveness on the Ground: A Methodological Framework. Aid for Trade Series, Issue Paper No. 20, International Centre for Trade and Sustainable Development, Geneva, Switzerland.

Bearce D Finkel S E, Pérez Liñán A, Rodriquez-Zepeda J, Surzhko-Harned L (2013). Has Aid for Trade Increased Recipient Exports? The Impact of US AfT Allocations 1999-2008. International Studies Quarterly, Vol. 57 (1), pp.163-170.

Busse, M., Hoekstra, R. and Königer, J. (2011). The impact of aid for trade facilitation on the costs of trading. Paper presented at CSAE 2011.

Calì M and Te Velde D (2011). Does Aid for Trade Really Improve Trade Performance? World Development, Vol. 39(5), pp. 725-740.

Canay, I. (2011). A Simple Approach to Quantile Regression for Panel Data" The Econometrics Journal 14, 368-386.

CEPII (2013a). CEPII’s Databases. Distances (geo_cepii, dist_cepii).

http://www.cepii.fr/anglaisgraph/bdd/bdd.htm. Accessed: 20/09/13.

Doucouliagos, H and Paldam, M (2008). Aid effectiveness on growth: A meta study. The European Journal of Political Economy, 248(1), 1-24.

Foreign Policy (2011). The Failed States Index 2011.

Available online: http://www.foreignpolicy.com/failedstates. Accessed: 20/09/13.

García, M (2008) Monitoring Aid for Trade, London, CUTS, $5^{\text {th }}$ June 2008, http://www.cutslondon.org/events/documents/CUTS05jun.pdf.

Hanke S (2008). Zimbabwe: From Hyperinflation to Growth. The Cato Institute. Development Policy Analysis, 2008, No. 6.

Available online: http://www.cato.org/pub_display.php?pub_id=9484.Accessed: $20 / 09 / 13$

Harris C (1954). The Market as a Factor in the Localization of Industry in the United States. Annals of the Association of American Geographers, Vol. 44(4), pp.315-348.

Helble M, Mann C and Wilson J (2012). Aid for Trade Facilitation. Review of World Economics $148(2), 357-376$.

Hoechle D (2007). Robust Standard Errors for Panel Regressions with Cross-sectional Dependence. The Stata Journal, Vol. 7(3), pp. 281-312. 
Huchet-Bourdon, M, Lipchitz, A and Rousson, A (2009) Aid for Trade in Developing Countries: Complex Linkages for Real Effectiveness. African Development Review, 21(2), 243-290.

Hühne, P, Meyer, B and Nunnenkamp, P (2014) Who Benefits from Aid for Trade? Comparing the Effects on Recipient versus Donor Exports. Journal of Development Studies 50 (9) $.1275-1288$.

Karingi, S (2009) Towards the Global Review of Aid for Trade 2009. Issues and State of Implementation in Africa. UN Economic Commission for Africa. http://www1.uneca.org. Accessed 28/01/14.

Luke, D (2009) Africa and Aid for Trade: What are the Trends? What are the Issues? AFRICAVIEWPOINT No. 11, August 2009. Regional Bureau for Africa. United Nations Development Programme (UNDP).

http://www.undg.org/Africa/africaviewpoint/2009-august.pdf.

Lutz W and KC S (2010). Dimensions of Global Population Projections: What Do We Know About Future Population Trends and Structures? Philosophical Transactions of the Royal Society B, Vol. 365, pp. 2779-2791.

Nowak-Lehmann D., F, Dreher, A, Herzer, D, Klasen, S and Martínez-Zarzoso, I (2012). Does foreign aid really raise per capita income? A time series perspective. Canadian Journal of Economics, 45(1), 288-313.

Nowak-Lehmann, F, Martínez-Zarzoso, I, Herzer, D, Klasen, S and Cardozo, A (2013). Does foreign aid promote exports to donor countries? Review of World Economics, 149(3), $505-535$.

OECD/WTO (2011). Aid for Trade and LDCs: Starting to Show Results.

Available online: http://www.oecd.org/dataoecd/18/53/47706423.pdf. Accessed: 20/09/13.

OECD (2013a). Creditor Reporting System (CRS) Database. http://stats.oecd.org/Index.aspx?DataSetCode=CRSNEW. Accessed: 20/09/13.

OECD (2013b). Creditor Reporting System (CRS) Database. Metadata. Database Specific. Abstract.

http://stats.oecd.org/Index.aspx?DataSetCode=CRSNEW. Accessed: 20/09/13.

OECD (2013c). Aid-for-Trade Proxies.

Available online: http://www.oecd.org/dataoecd/29/1/39880833.pdf. Accessed: 20/09/13. 
OECD (2014) Aid for Trade. http://www.oecd.org/dac/aft/aid-for-tradestatisticalqueries.html Accessed 28/01/14.

Overman H, Redding S and Venables A (2001). The Economic Geography of Trade Production and Income: A Survey of Empirics. Centre for Economic Policy Research (CEPR). Discussion Paper (2978).

Rajan, R and Subramanian, A (2008) Aid and growth: What does the cross-country evidence really show? Review of Economics and Statistics, 90(4), 643-665.

Vijil M and Wagner L (2012). Does Aid for Trade Enhance Export Performance? Investigating on the Infrastructure Channel. World Economy 35 (7), 838-868.

Wooldridge J (2001). Econometric Analysis of Cross Section and Panel Data. Cambridge, MA: MIT Press.

Wooldridge J (2003). Introductory Econometrics: A Modern Approach, 2nd ed. Cincinnati, OH: South-Western College Publishing.

World Bank (2013a). World Development Indicators (WDI). http://databank.worldbank.org/ddp/home.do. Accessed: 20/09/13.

World Bank (2013b). Worldwide Governance Indicators (WGI). http://info.worldbank.org/governance/wgi/index.asp. Accessed: 20/09/13. 
Table A.1. Composition of AfT categories

\begin{tabular}{|c|c|c|c|c|}
\hline $\begin{array}{l}\text { Sector- } \\
\text { number }\end{array}$ & Sector & $\begin{array}{c}\text { AfT-proxy / Aid- } \\
\text { proxy } \\
\end{array}$ & Abbr. & \\
\hline 331 & Trade Policy and Regulations & $\begin{array}{c}\text { Trade Policy and } \\
\text { Regulations } \\
\text { (TPR) }\end{array}$ & A4T_TPR & \\
\hline $\begin{array}{l}210 \\
220 \\
230 \\
240 \\
250\end{array}$ & $\begin{array}{l}\text { Transport and Storage } \\
\text { Communications } \\
\text { Energy Generation and Supply } \\
\text { Banking and Financial Services } \\
\text { Business and Other Services }\end{array}$ & $\begin{array}{c}\text { Economic } \\
\text { Infrastructure } \\
(E I)\end{array}$ & A4T_EI & 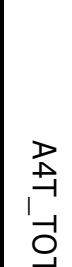 \\
\hline $\begin{array}{l}311 \\
312 \\
313 \\
321 \\
322 \\
332\end{array}$ & $\begin{array}{c}\text { Agriculture } \\
\text { Forestry } \\
\text { Fishing } \\
\text { Industry } \\
\text { Mineral Resources and Mining } \\
\text { Tourism }\end{array}$ & $\begin{array}{l}\text { Building Productive } \\
\text { Capacity (BPC) }\end{array}$ & A4T_BPC & \\
\hline
\end{tabular}

Notes: Illustrations are based partly on OECD (2013c). AfT proxies are calculated as the sum of ODA for the three corresponding sectors as shown in the table. For example, EI is calculated as the sum of ODA for the five subsectors, "Transport and Storage", "Communications", "Energy Generation and Supply", "Banking and Financial Services" and "Business and other Services". If data on ODA for some sectors was missing, the AfT proxy was calculated as the sum of ODA for the other sectors, i.e. when calculating the sum over all corresponding sectors, missing values are set equal to 0 as long as all values are missing (in which case the AfT proxy would be missing too). Abbr.: Abbreviations. 
Table A.2. ADF Fisher unit root tests

\begin{tabular}{|l|l|l|}
\hline & $\begin{array}{l}\text { ADF-Fisher Chi-square } \\
\text { statistic }\end{array}$ & p-value \\
\hline Ln exports & 201.94 & 0.68 \\
\hline LnAfT & 185.73 & 1.00 \\
\hline LnAfT_TPR & 177.15 & 0.23 \\
\hline LnAfT_EI & 211.83 & 0.99 \\
\hline LnAfT_BPC & 272.19 & 0.45 \\
\hline LnAid_GBS & 41.89 & 0.96 \\
\hline Pop & 186.87 & 1.00 \\
\hline LnMp1 & 89.15 & 1.00 \\
\hline GE & 272.67 & 0.81 \\
\hline LnCpi & 176.80 & 1.00 \\
\hline & & \\
\hline
\end{tabular}

Note: Null hypothesis: Unit root, ie. the series is non-stationary. Probabilities for Fisher ADF tests are calculated using an asymptotic Chi-square distribution.

Table A.3. Kao's residual cointegration test and Pesaran's (2011) cointegration test

\begin{tabular}{|l|l|lc|}
\hline Kao & ADF t-statistic & p-value \\
\hline $\begin{array}{l}\text { Cointegration between lnExports, } \\
\text { LnAfT, LnAid_GBS, Pop, LnMp1, GE, } \\
\text { LnCpi }\end{array}$ & $1.32^{*}$ & 0.09 \\
\hline $\begin{array}{l}\text { Cointegration between lnExports, } \\
\text { LnAfT_TPR, LnAfT_EI, LnAfT_BPC, } \\
\text { LnAid_GBS, Pop, LnMp1, GE, LnCpi }\end{array}$ & $2.93^{* * *}$ & 0.01 \\
\hline $\begin{array}{l}\text { Pesaran's et al. (2011) ARDL bounds } \\
\text { testing }\end{array}$ & F-statistic & $\begin{array}{l}\text { Pesaran's critical } \\
\text { values }\end{array}$ \\
\hline $\begin{array}{l}\text { Cointegration between lnExports, } \\
\text { LnAfT, LnAid_GBS, Pop, LnMp1, GE, } \\
\text { LnCpi }\end{array}$ & $14.46^{* * *} \mathrm{~F}(7,251)$ & I(0) \\
\hline $\begin{array}{l}\text { Cointegration between lnExports, } \\
\text { LnAfT_TPR, LnAfT_EI, LnAfT_BPC, } \\
\text { LnAid_GBS, Pop, LnMp1, GE, LnCpi }\end{array}$ & $1.67 \mathrm{E}+11^{* * *} \mathrm{~F}(9,196)$ & 2.96 \\
\hline
\end{tabular}

Note: Null hypothesis: No cointegration, respectively the right-hand side variables are not significantly different from zero. 
Table A.4. List of countries

\begin{tabular}{|c|c|c|}
\hline Afghanistan & Equatorial Guinea & Pakistan \\
\hline Angola & Grenada & Panama \\
\hline Albania & Guatemala & Peru \\
\hline Argentina & Guyana & Philippine \\
\hline Armenia & Honduras & Palau \\
\hline Antigua and Barbuda & Croatia & Papua New Guinea \\
\hline Azerbaijan & Haiti & Paraguay \\
\hline Burundi & Indonesia & Rwanda \\
\hline Benin & India & Saudi Arabia \\
\hline Burkina Faso & Iran, Islamic Rep. & Sudan \\
\hline Bangladesh & Iraq (no exports) & Senegal \\
\hline Bahrain & Jamaica & Solomon Islands \\
\hline Bosnia and Herzegovina & Jordan & Sierra Leone \\
\hline Belarus & Kazakhstan & El Salvador \\
\hline Belize & Kenya & Sao Tome and Principe \\
\hline Bolivia & Kyrgyz Republic & Suriname \\
\hline Brazil & Cambodia & Slovenia \\
\hline Barbados & St. Kitts and Nevis & Swaziland \\
\hline Bhutan & Lao PDR & Seychelles \\
\hline Botswana & Lebanon & Syrian Arab Republic \\
\hline Central African Republic & Liberia & Chad \\
\hline Chile & Libya & Togo \\
\hline China & St. Lucia & Thailand \\
\hline Cote d'Ivoire & Sri Lanka & Tajikistan \\
\hline Cameroon & Lesotho & Turkmenistan \\
\hline Congo, Rep. & Morocco & Tonga \\
\hline Colombia & Moldova & Trinidad and Tobago \\
\hline Comoros & Madagascar & Tunisia \\
\hline Cape Verde & Maldives & Turkey \\
\hline Costa Rica & Mexico & Tanzania \\
\hline Cuba & Macedonia, FYR & Uganda \\
\hline Djibouti & Mali & Ukraine \\
\hline Dominica & Malta & Uruguay \\
\hline Dominican Republic & Mongolia & Uzbekistan \\
\hline Algeria & Mozambique & St. Vincent and the Grenadines \\
\hline Ecuador & Mauritania & Venezuela, RB \\
\hline Egypt, Arab Rep. & Mauritius & Vietnam \\
\hline Eritrea & Malawi & Vanuatu \\
\hline Ethiopia & Malaysia & Samoa \\
\hline Fiji & Namibia & Yemen, Rep. \\
\hline Gabon & Niger & South Africa \\
\hline Georgia & Nigeria & Congo, Dem. Rep. \\
\hline Ghana & Nicaragua & Zambia \\
\hline Guinea & Nepal & Zimbabwe \\
\hline Gambia, The & Oman & \\
\hline
\end{tabular}


Table A.5. List of variables, abbreviations, description and sources

\begin{tabular}{|c|c|c|c|}
\hline & Variable & Variable description & Source \\
\hline \multirow{10}{*}{ 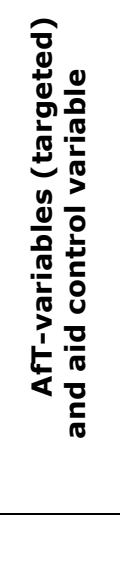 } & C_TPR & A4T proxy for Trade Policy and Regulations; Commitments* & own calculations; CRS \\
\hline & C_EI & A4T proxy for Economic Infrastructure; Commitments* & own calculations; CRS \\
\hline & C_BPC & A4T proxy for Building Productive Capacity; Commitments* & own calculations; CRS \\
\hline & C_TOTAL & A4T proxy Total; Commitments* & own calculations; CRS \\
\hline & C_GBS & $\begin{array}{l}\text { Untargeted AID, proxy for General Budget Support; } \\
\text { Commitments* }\end{array}$ & own calculations; CRS \\
\hline & D_TPR & A4T proxy for Trade Policy and Regulations; Disb. gross* & own calculations; CRS \\
\hline & D_EI & A4T proxy for Economic Infrastructure; Disb. gross* & own calculations; CRS \\
\hline & D_BPC & A4T proxy for Building Production Capacity; Disb. gross* & own calculations; CRS \\
\hline & D_TOTAL & A4T proxy Total; Disbursements gross* & own calculations; CRS \\
\hline & D_GBS & Untargeted AID, proxy for General Budget Support; Disb. gross* & own calculations; CRS \\
\hline \multirow{5}{*}{ 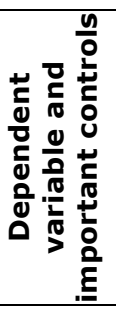 } & Exports & Exports of goods and services (constant 2005 USD millions) & WDI \\
\hline & Population & Population, total (in millions) & WDI \\
\hline & MP1 & Market Potential 1 (with simple distances) & own calc.; WDI, CEPII \\
\hline & GE & $\begin{array}{l}\text { Government Effectiveness }(-2.5=\text { weak to } 2.5=\text { strong gov. } \\
\text { performance) }\end{array}$ & WGI \\
\hline & CPI & Consumer price index $(2005=100)$ & WDI \\
\hline \multirow{3}{*}{$\begin{array}{l}\frac{n}{0} \\
\frac{1}{0} \\
\frac{1}{2} \\
0 \\
0\end{array}$} & MP2 & Market Potential 2 (with square root distances) & own calc.; WDI, CEPII \\
\hline & MP3 & Market Potential 3 (with squared distances) & own calc.; WDI, CEPII \\
\hline & SOLR & Strength of legal rights index ( $0=$ weak to $10=$ strong $)$ & WDI \\
\hline
\end{tabular}

Notes: * constant 2011 US\$ millions. CEPII: Centre d'Etudes Prospectives et d'Informations Internationales, CEPII (2011a/b); CRS: Creditor Reporting System, OECD (2013a); Disb.: Disbursements; Gov.: government or governance; own calc.: own calculations; WDI: World Development Indicators, World Bank (2011a); WGI: World Governance Indicators, World Bank (2011b).

Table A.6. AfT commitments and disbursements

\begin{tabular}{|l|l|l|l|l|l|}
\hline $\begin{array}{l}\text { Target } \\
\text { Variables }\end{array}$ & Obs & Mean & Std. Dev. & Min & Max \\
\hline Commitments & \multicolumn{7}{|l|}{} \\
\hline C_TPR & 1312 & 4.631 & 17.779 & 0.000 & 461.053 \\
\hline C_EI & 1662 & 142.824 & 317.260 & 0.000 & 4264.45 \\
\hline C_BPC & 1684 & 58.618 & 119.746 & 0.000 & 1926.927 \\
\hline C_TOTAL & 1699 & 201.391 & 409.525 & 0.000 & 5375.200 \\
\hline C_GBS & 810 & 87.058 & 159.957 & 0.00 & 1730.520 \\
\hline Disbursements & \multicolumn{5}{|l|}{} \\
\hline D_TPR & 1204 & 3.360 & 15.781 & 0.000 & 403.724 \\
\hline D_EI & 1404 & 103.006 & 217.144 & 0.006 & 2386.488 \\
\hline D_BPC & 1415 & 44.714 & 80.960 & 0.003 & 775.843 \\
\hline D_TOTAL & 1425 & 148.7273 & 288.606 & 0.003 & 3042.281 \\
\hline D_GBS & 742 & 70.240 & 122.008 & 0.00 & 1066.810 \\
\hline
\end{tabular}


Table A.7. Percentiles for C_TOTAL and D_TOTAL

\begin{tabular}{|l|r|r|r|r|r|r|}
\hline Percentiles & $1 \%$ & $10 \%$ & $25 \%$ & $50 \%$ & $75 \%$ & $99 \%$ \\
\hline Aid Com & 0.130 & 3.681 & 15.775 & 73.078 & 259.225 & 2160.135 \\
\hline Aid Dis & 0.257 & 3.949 & 15.848 & 63.060 & 199.951 & 1598.119 \\
\hline
\end{tabular}

Source: Figures in constant 2011 US\$ millions. Authors' calculations with data from Creditor Reporting System, OECD (2013a). Disbursement figures are higher than commitment figures due to a higher number of missing values in the disbursement figures (363) than in the commitment ones. 
Table A.8. Results with the second lag of AfT for Total AfT and subcategories

\begin{tabular}{|c|c|c|c|c|}
\hline & $\begin{array}{l}\text { (1) } \\
\text { M1(Q.1) }\end{array}$ & $\begin{array}{l}(2) \\
\text { M2(Q.25) }\end{array}$ & $\begin{array}{l}(3) \\
\text { M3(Q.5) }\end{array}$ & $\begin{array}{l}(4) \\
\text { M4(Q.75) }\end{array}$ \\
\hline \multirow{2}{*}{$\begin{array}{l}12 \operatorname{lnD} \\
\text { TOTAL }\end{array}$} & 0.0150 & $0.012 * *$ & $0.025 * * *$ & $0.029 * * *$ \\
\hline & $(0.01)$ & $(0.01)$ & $(0.00)$ & $(0.00)$ \\
\hline $12 \operatorname{lnD}$ GBS & $\begin{array}{l}-0.012 * * \\
(0.00)\end{array}$ & $\begin{array}{l}-0.007 * * * \\
(0.00)\end{array}$ & $\begin{array}{l}-0.004 * * \\
(0.00)\end{array}$ & $\begin{array}{l}-0.00200 \\
(0.00)\end{array}$ \\
\hline Nobs & 417 & 417 & 417 & 417 \\
\hline \multirow[t]{3}{*}{$\mathrm{R} 2 \mathrm{a}$} & 0.955 & 0.956 & 0.959 & 0.958 \\
\hline & (1) & (2) & (3) & (4) \\
\hline & M1(Q.1) & $\mathrm{M} 2(\mathrm{Q} .25)$ & M3(Q.5) & $\mathrm{M} 4(\mathrm{Q} .75)$ \\
\hline \multirow[t]{2}{*}{$12 \operatorname{lnD} \mathrm{TPR}$} & $-0.010 *$ & $-0.009^{*}$ & -0.00600 & $-0.016 * * *$ \\
\hline & $(0.01)$ & $(0.01)$ & $(0.01)$ & $(0.00)$ \\
\hline \multirow[t]{2}{*}{$12 \operatorname{lnD} \mathrm{EI}$} & 0.0180 & 0.00600 & $0.007 * *$ & $0.013^{* * *}$ \\
\hline & $(0.01)$ & $(0.01)$ & $(0.00)$ & $(0.00)$ \\
\hline \multirow{2}{*}{$12 \operatorname{lnD} \mathrm{BPC}$} & 0.0180 & $0.037 * * *$ & $0.044 * * *$ & $0.050 * * *$ \\
\hline & $(0.02)$ & $(0.01)$ & $(0.01)$ & $(0.01)$ \\
\hline \multirow[t]{2}{*}{$12 \operatorname{lnD}$ GBS } & -0.00600 & $-0.008 * * *$ & -0.00300 & -0.00200 \\
\hline & $(0.00)$ & $(0.00)$ & $(0.00)$ & $(0.00)$ \\
\hline Nobs & 356 & 356 & 356 & 356 \\
\hline $\mathrm{R} 2 \mathrm{a}$ & 0.946 & 0.949 & 0.951 & 0.950 \\
\hline
\end{tabular}

Notes: Dependent variable: In (Exports of goods and services in constant 2005 US\$ millions). The FE used to transform exports are from the fixed effect regression. Key explanatory variable: total AfT disbursements. The same control variables as in Tables 3 and 4 are included as well as time fixed effects. The corresponding coefficients are not reported to save space. Robust standard errors are in brackets. ${ }^{*} p<0.10, * * p<0.05, * * * p<0.01$. 
Table A9: PPML regression results

\begin{tabular}{|c|c|c|c|c|}
\hline & $\begin{array}{c}\text { (1) } \\
\text { M1(Poi) }\end{array}$ & $\begin{array}{c}\text { (2) } \\
\text { M2(Poi) }\end{array}$ & $\begin{array}{c}(3) \\
\text { M3(FEPoi) }\end{array}$ & $\begin{array}{c}\text { (4) } \\
\text { M4(FEPoi) }\end{array}$ \\
\hline $12 \ln \mathrm{D}$ TOTAL & $\begin{array}{c}0.530 * * * \\
(0.08)\end{array}$ & & $\begin{array}{c}-0.0450 \\
(0.05)\end{array}$ & \\
\hline $12 \operatorname{lnD} \mathrm{TPR}$ & & $\begin{array}{c}0.157 * * * \\
(0.05)\end{array}$ & & $\begin{array}{c}-0.0260 \\
(0.02)\end{array}$ \\
\hline $12 \operatorname{lnD} \mathrm{EI}$ & & $\begin{array}{c}0.0980 \\
(0.08)\end{array}$ & & $\begin{array}{c}0.0310 \\
(0.03)\end{array}$ \\
\hline $12 \operatorname{lnD} \mathrm{BPC}$ & & $\begin{array}{c}0.232 * * * \\
(0.09)\end{array}$ & & $\begin{array}{l}-0.140 \\
(0.09)\end{array}$ \\
\hline $12 \operatorname{lnD}$ GBS & $\begin{array}{c}-0.216^{* * *} \\
(0.02)\end{array}$ & $\begin{array}{c}-0.181 * * * \\
(0.02)\end{array}$ & $\begin{array}{c}-0.00700 \\
(0.01)\end{array}$ & $\begin{array}{c}-0.0130 \\
(0.01)\end{array}$ \\
\hline Population & $\begin{array}{c}0.002 * * * \\
(0.00)\end{array}$ & $\begin{array}{c}0.002 * * * \\
(0.00)\end{array}$ & $\begin{array}{c}0.004 * * * \\
(0.00)\end{array}$ & $\begin{array}{c}0.004 * * * \\
(0.00)\end{array}$ \\
\hline $\ln$ MP1 & $\begin{array}{c}-1.465^{* * *} \\
(0.42)\end{array}$ & $\begin{array}{c}-1.176^{* * *} \\
(0.41)\end{array}$ & $\begin{array}{c}4.027 * * \\
(1.75)\end{array}$ & $\begin{array}{c}3.263 * * * \\
(1.26)\end{array}$ \\
\hline GE & $\begin{array}{c}1.026^{* * *} \\
(0.16)\end{array}$ & $\begin{array}{c}1.034 * * * \\
(0.19)\end{array}$ & $\begin{array}{l}0.474 \\
(0.35)\end{array}$ & $\begin{array}{l}0.521 \\
(0.36)\end{array}$ \\
\hline $\ln \mathrm{CPI}$ & $\begin{array}{l}-0.179 \\
(0.28)\end{array}$ & $\begin{array}{c}-0.0580 \\
(0.19)\end{array}$ & $\begin{array}{c}-0.0180 \\
(0.05)\end{array}$ & $\begin{array}{c}-0.00900 \\
(0.05)\end{array}$ \\
\hline Africa Dummy & $\begin{array}{c}-2.308^{* * *} \\
(0.63)\end{array}$ & $\begin{array}{c}-1.503 * * \\
(0.76)\end{array}$ & & \\
\hline America Dummy & $\begin{array}{c}-1.291 * * \\
(0.65)\end{array}$ & $\begin{array}{l}-0.628 \\
(0.78)\end{array}$ & & \\
\hline Asia Dummy & $\begin{array}{c}-1.291 * * \\
(0.54)\end{array}$ & $\begin{array}{l}-0.615 \\
(0.70)\end{array}$ & & \\
\hline Pacific Dummy & $\begin{array}{c}-5.548^{* * *} \\
(1.06)\end{array}$ & $\begin{array}{c}-4.335^{* * *} \\
(1.22)\end{array}$ & & \\
\hline Constant & $\begin{array}{c}18.315^{* * *} \\
(4.45)\end{array}$ & $\begin{array}{c}15.876^{* * *} \\
(4.29)\end{array}$ & & \\
\hline Nobs & 550 & 461 & 507 & 401 \\
\hline
\end{tabular}


Figure A.1. Regional distribution of countries included in our analysis

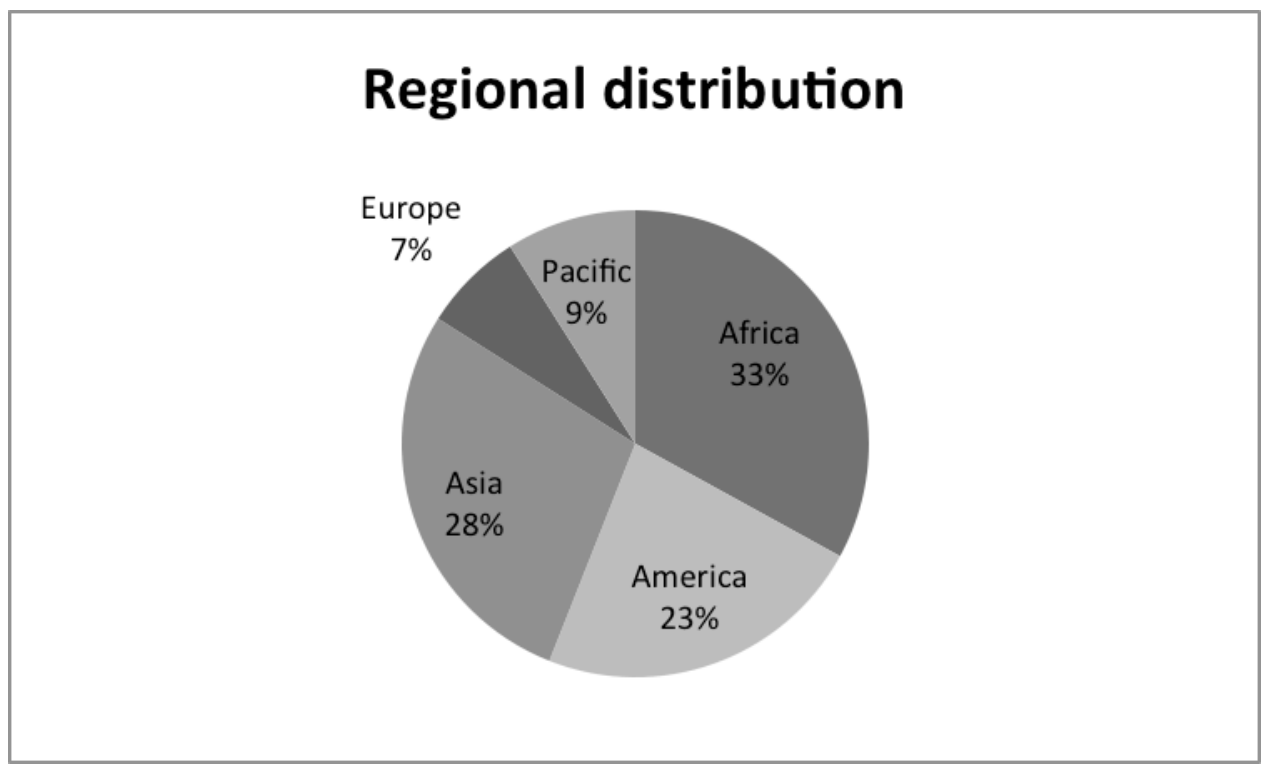

Notes: Figures based on author's calculations. Data are from CEPII (2011a). Shares add up to 1. 